\title{
$\alpha$-D-Glucuronidases from the xylanolytic thermophiles Clostridium stercorarium and Thermoanaerobacterium saccharolyticum
}

\author{
Karin Bronnenmeier, Harald Meissner, Susanne Stocker \\ and Walter L. Staudenbauer
}

Author for correspondence: Karin Bronnenmeier. Tel: +4989 2105 2637. Fax: +498921052360.

Lehrstuhl für Mikrobiologie, Technische Universităt Müchen, Arcisstraße 16, D80290 München, Germany

\begin{abstract}
$\alpha$-D-Glucuronidases were purified from the xylanolytic thermophiles Clostridium stercorarium and Thermoanaerobacterium saccharolyticum. This enzyme activity was found to be intracellular in each organism, with $\boldsymbol{T}$. saccharolyticum producing much greater total activity. The specific activities of the purified enzymes $\left(10 \mathrm{U} \mathrm{mg}^{-1} \mathrm{~T}\right.$. saccharolyticum ; $1.7 \mathrm{U} \mathrm{mg}^{-1} \mathrm{C}$. stercorarium) differed by a factor of approximately 5 . For the determination of enzyme activities, 4-0-methyl- $\alpha$-D-glucuronosyl-xylotriose was used as a substrate and the glucuronic acid released by $\alpha$-D-glucuronidase action was quantified by a colorimetric procedure. 4-0-Methyl- $\alpha$-D-glucuronosyl-xylotriose was the hydrolysis product that accumulated after exhaustive degradation of 4-O-methyl- $\alpha$-D-glucuronoxylan with xylanases of C. stercorarium. Hydrolysis of side chains in high-molecular-mass glucuronoxylan could not be detected. Neither of the enzymes was able to hydrolyse the chromogenic aryl-substrate p-nitrophenyl- $\alpha$-D-glucuronoside. Both $\alpha$-D-glucuronidases have a dimeric structure, with monomeric molecular masses of 72 and $76 \mathrm{kDa}$ for $\mathrm{C}$. stercorarium and of $71 \mathrm{kDa}$ for $\mathrm{T}$. saccharolyticum. The pl was estimated to be 4.3 for each enzyme. While both enzymes exhibited a similar pH optimum (pH 5.5-6.5) they differed in their thermostabilities. At $60{ }^{\circ} \mathrm{C}$, half-lives of 14 and $2.5 \mathrm{~h}$, respectively, were determined for the $\alpha$-D-glucuronidases of $C$. stercorarium and $T$. saccharolyticum. This description of $\alpha$-D-glucuronidase activity in thermophilic anaerobic bacteria extends our knowledge of these enzymes, previously purified and characterized only in fungi.
\end{abstract}

Keywords: $\alpha$-D-glucuronidases, Clostridium, Thermoanaerobacterium, thermoactive enzymes, xylan

\section{INTRODUCTION}

Xylans are the most abundant noncellulosic polysaccharides in angiosperms, where they account for $20-30 \%$ of the dry weight of woody tissues (Aspinall, 1980). Xylans from different sources exhibit considerable variation in composition and structure (Coughlan \& Hazlewood, 1993). However, most xylans consist of a homopolymeric backbone chain of $\beta$-1,4-linked $\mathrm{D}$ xylopyranosyl residues. The backbone may be substituted with $\alpha$-1,3-linked L-arabinofuranosyl and $\alpha$-1,2-linked 4-

Abbreviations: mGICAX3, 4-O-methyl- $\alpha$-D-glucuronosyl-xylotriose; AMPSO, 3-[(1,1-dimethyl-2-hydroxyethyl)amino]-2-hydroxypropanesulfonic acid.
$O$-methylglucuronic acid residues as well as with acetic, $p$ coumaric and ferulic acids. Complete hydrolysis of these complex heteropolysaccharides requires the interaction of various main-chain- and side-chain-cleaving activities. Endo- $\beta$-1,4-xylanases $(1,4-\beta$-D-xylan xylanohydrolase, EC 3.2.1.8), $\beta$-D-xylosidases $(1,4-\beta$-D-xyloside xylohydrolase, EC 3.2.1.37) and possibly exo- $\beta$-1,4-xylanases (1,4- $\beta$-D-xylan xylohydrolase) are involved in the hydrolysis of the xylan backbone. Removal of side groups is catalysed by $\alpha$-L-arabinofuranosidases (EC 3.2.1.55) and $\alpha$-D-glucuronidases (EC 3.2.1). Esterase activities are responsible for the liberation of acetyl, coumaryl and feruloyl substituents (Coughlan \& Hazlewood, 1993).

Xylanolytic enzymes are produced by a wide variety of micro-organisms. However, due to the lack of a suitable 
routine assay system, $\alpha$-D-glucuronidase has been isolated and characterized from only a few, and exclusively fungal, sources (Puls et al., 1987; Khandke et al., 1989; Uchida et al., 1992; Siika-aho et al., 1994). An $\alpha$-D-glucuronidase has not been purified from bacteria up to now. We selected the saccharolytic thermoanaerobic bacteria Clostridium stercorarium and Thermoanaerobacterium saccharolyticum as candidates for $\alpha$-D-glucuronidase production. $C$. stercorarium (Madden, 1983) produces a complete enzyme system for the degradation of arabinoxylan, which includes xylanase, $\beta$-D-xylosidase and $\alpha$-L-arabinofuranosidase activities (Bronnenmeier et al., 1990; Schwarz et al., 1990). The species T. saccbarolyticum (Lee et al., 1933a) contains two closely related isolates from geothermal sources originally described as Thermoanaerobacter strain B6A (Weimer et al., 1984) and strain B6A-RI (Lee et al., 1993a). Both strains hydrolysed xylan extensively (Weimer, 1985; Lee et al., 1993b), and strain B6A was shown to produce and utilize uronic acids in addition to monosaccharide degradation products during growth on various xylan preparations (Hespell, 1992).

This paper reports the identification, purification and characterization of $\alpha$-D-glucuronidases from $C$. stercorarium and T. saccharolyticum strain B6A.

\section{METHODS}

Organisms and culture conditions. Clostridium stercorarium NCIB 11754 was obtained from the National Collection of Industrial and Marine Bacteria, Aberdeen, UK. It was grown under anaerobic conditions at $65^{\circ} \mathrm{C}$ in GS-2 medium (Johnson et al., 1981) with $0.5 \%$ xylan from birchwood (Sigma) as carbon source.

Thermoanaerobacterium saccharolyticum B6A (Weimer et al., 1984; Lee et al., 1993a) was obtained from R. Hespell (National Center for Agricultural Utilisation Research, Peoria, USA). It was grown under anaerobic conditions at $60^{\circ} \mathrm{C}$ in $\mathrm{CM} 5$ medium (Weimer et al., 1984) supplemented with $0.2 \%$ yeast extract and $0.3 \%$ tryptone. Xylan from birchwood $(0.5 \%)$ was added as carbon source.

Since the xylan preparation used proved to be completely soluble, the increase in $\mathrm{OD}_{600}$ could be used to follow growth of $C$. stercorarium and $T$. saccharolyticum cultures. After the stationary phase was reached, cultivation was continued for $12 \mathrm{~h}$ before the cells were harvested.

E. coli JM83(WS1259) and E. coli JM109(WS1231), which bear the $C$. stercorarium genes $x y n A$ and celX described previously (Schwarz et al., 1990), were grown at $37^{\circ} \mathrm{C}$ in Luria broth (LB) containing (per litre): $10 \mathrm{~g}$ tryptone, 5 g yeast extract, $5 \mathrm{~g} \mathrm{NaCl}$, and $1 \mathrm{~g}$ glucose, $\mathrm{pH} 7 \cdot 5$. Ampicillin was added at a concentration of $100 \mu \mathrm{g} \mathrm{ml}^{-1}$.

\section{Determination of $\alpha$-D-glucuronidase activity}

Preparation of the substrate. Since a requirement for a lowmolecular-mass glucuronoxylan substrate has been reported for the fungal $\alpha$-D-glucuronidases characterized thus far (Puls $e t$ al., 1987; Puls \& Poutanen, 1989; Khandke et al., 1989; Uchida et al., 1992), we prepared 4-O-methyl- $\alpha$-D-glucuronosyl-xylotriose (aldotetraouronic acid, $\operatorname{mGlcAX} 3$ ) from 4-O-methyl- $\alpha$-Dglucuronoxylan. $\quad 4-O-$ Methyl- $\alpha$-D-glucuronoxylan $\quad(3.77 \mathrm{~g}$,
Sigma) was incubated with crude extracts $(20 \mathrm{ml}$ each, derived from approximately $10 \mathrm{~g}$ of cells) of E. coli JM83(WS1259) and E. coli JM109(WS1231) (Schwarz et al., 1990), expressing xylanase $\mathrm{A}$ and celloxylanase $\mathrm{X}$ from $C$. stercorarium, in $50 \mathrm{mM}$ ammonium acetate, $\mathrm{pH} 6.0$, with $0.02 \%$ sodium azide, at $60^{\circ} \mathrm{C}$ for $78 \mathrm{~h}$. The hydrolysate was cleared by centrifugation and incubated for $15 \mathrm{~min}$ at $100^{\circ} \mathrm{C}$ in order to remove ammonium acetate. The enzymic degradation of the xylan substrate resulted in the formation of xylose, xylobiose, and two acidic oligosaccharides. Fractionation of the xylan hydrolysate was achieved by anion-exchange chromatography. The hydrolysate $(310 \mathrm{ml})$ was applied to a $\mathrm{K} 50 / 60$ column packed with AG 1-X8, 100-200 mesh, $\mathrm{AC}^{-}$(Bio-Rad) and equilibrated with distilled water. Neutral sugars were eluted with distilled water $(2700 \mathrm{ml})$; the acidic oligosaccharides were released from the column with $80 \mathrm{mM}$ ammonium acetate, $\mathrm{pH} 5.9(2700 \mathrm{ml})$. Fractions $(20 \mathrm{ml})$ were collected and assayed for reducing sugars. $\alpha$-DGlucuronosyl-xylotriose was identified by TLC and HPLC using mGlcAX3 purchased from Megazyme as a standard. Furthermore, the putative mGlcAX3 was shown to contain hexuronic acid with the colorimetric reagent 3,5-dimethylphenol (Scott, 1979).

Enzyme assay. $\alpha$-D-Glucuronidase activity was determined by measuring the release of $4-O$-methyl- $\alpha$-D-glucuronic acid from mGlcAX3 with a modification of the colorimetric procedure described by Khandke et al. (1989), which is based on the method developed by Milner \& Avigad (1967). We reduced the concentration of the acidic substrate to $0.7 \mathrm{mM}$. In order to increase the sensitivity of the assay the absorbance was read at $710 \mathrm{~nm}$. One unit (U) of activity is defined as the amount of enzyme required to release $1 \mu \mathrm{mol} 4-O$-methyl- $\alpha$-D-glucuronic acid $\min ^{-1}$.

Buffers used for the determination of the $\mathrm{pH}$ profiles were $100 \mathrm{mM}$ ammonium acetate (pH 3.5-5.5), $100 \mathrm{mM}$ sodium

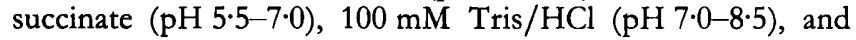
$100 \mathrm{mM}$ AMPSO (pH 8.5-9.5). The $\mathrm{pH}$ values of buffers were adjusted at the temperatures of use.

Assays for other xylanolytic enzyme activities. $\alpha$-L-Arabinofuranosidase and $\beta$-xylosidase activities were determined by measuring the release of $p$-nitrophenol from the corresponding $p$-nitrophenyl glycoside (Sigma) at $60^{\circ} \mathrm{C}$ in $0.1 \mathrm{M}$ sodium succinate, $\mathrm{pH} 6.0$. One unit of activity is defined as the amount of enzyme liberating $1 \mu \mathrm{mol} p$-nitrophenol $\mathrm{min}^{-1}$. The hydrolysis of $p$-nitrophenyl $\alpha$-D-glucuronoside was determined with an equivalent assay procedure. The substrate was synthesized via catalytic oxidation of $p$-nitrophenyl $\alpha$-D-glucopyranoside (Sigma) as described by Marsh (1952) and Marsh \& Levvy (1958).

Xylanase activity was assayed by determination of the reducing sugars released during incubation for an appropriate time at $60^{\circ} \mathrm{C}$ in a $0.5 \%(\mathrm{w} / \mathrm{v})$ solution of xylan from oat spelts (Sigma) in $0.1 \mathrm{M}$ sodium succinate, $\mathrm{pH} 6.0$. One unit (U) of enzyme corresponds to the release of $1 \mu \mathrm{mol}$ xylose equivalent $\mathrm{min}^{-1}$.

\section{Enzyme purification}

C. stercorarium. The cells from a $161 \mathrm{C}$. stercorarium culture were harvested by centrifugation, washed three times with $50 \mathrm{mM}$ Tris $/ \mathrm{HCl}, \mathrm{pH} 8 \cdot 0$, and suspended in $20 \mathrm{mM}$ Tris $/ \mathrm{HCl}, \mathrm{pH} 8 \cdot 0$. A cell extract was prepared by passage of lysozyme-treated cells (incubated for $30 \mathrm{~min}$ at $37^{\circ} \mathrm{C}$ with $1 \mathrm{mg}$ lysozyme ml $\mathrm{m}^{-1}$ ) through an Aminco French pressure cell. The lysate was incubated at $37^{\circ} \mathrm{C}$ with DNase I and RNase (each $20 \mu \mathrm{g} \mathrm{ml}^{-1}$ ). Debris was removed by centrifugation and the cleared cell extract was loaded on a Pharmacia Q Sepharose FF column. Anion-exchange chromatography was performed as described 
in the legend of Fig. 2(a). Solid $\mathrm{NaCl}$ was added to the pooled fractions (43-59) up to a concentration of $2 \mathrm{M}$. Hydrophobic interaction chromatography (HIC) was carried out on a Pharmacia Phenyl-Sepharose HP column as described in the legend of Fig. 2(b). After dialysis against equilibration buffer, pooled fractions (28-34) of the HIC column were loaded on a Pharmacia Mono Q HR 10/10 column equilibrated with $20 \mathrm{mM}$ L-histidine. $\mathrm{HCl}, \mathrm{pH} 6.0$. Elution was effected with a $160 \mathrm{ml}$ linear gradient $(0-0.4 \mathrm{M} \mathrm{LiCl})$ in equilibration buffer at a flow rate of $4 \mathrm{ml} \mathrm{min}^{-1}$. Fractions (26-31) were pooled and concentrated to $1.2 \mathrm{ml}$ in a Centriprep centrifugal microconcentrator (Amicon). Gel filtration was carried out on a Pharmacia Superdex 200 prep-grade HiLoad 16/60 column equilibrated with $20 \mathrm{mM}$ Tris $/ \mathrm{HCl}, \mathrm{pH} 7 \cdot 0$, containing $150 \mathrm{mM} \mathrm{NaCl}$, at a flow rate of $1 \mathrm{ml} \mathrm{min}^{-1}$. Apparent molecular masses were estimated from the partition coefficients as described previously (Bronnenmeier \& Staudenbauer, 1988). Chromatofocusing was performed on a Pharmacia Mono P HR 5/20 column equilibrated with $25 \mathrm{mM}$ L-histidine. $\mathrm{HCl}, \mathrm{pH} 5 \cdot 3$. The column was eluted with $44 \mathrm{ml}$ Pharmacia Polybuffer 74, diluted 1:10 and adjusted to $\mathrm{pH} 3.8$ with $\mathrm{HCl}$. Following dilution with 4 vols $20 \mathrm{mM}$ ammonium acetate, $\mathrm{pH} 5 \cdot 0$, the pooled fractions of the Mono P column were loaded on a Pharmacia Mono Q HR 5/5 column equilibrated with the same buffer. Elution was effected with a $20 \mathrm{ml}$ linear gradient $(0-0.4 \mathrm{M} \mathrm{NaCl})$ in equilibration

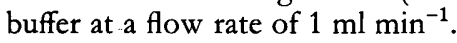

T. saccharolyticum. A crude extract of a $201 T$. saccharolyticum culture was prepared as described above. Anion-exchange chromatography was performed on a Pharmacia XK 50/20 column packed with $110 \mathrm{ml} Q$ Sepharose FF and equilibrated with $20 \mathrm{mM}$ Tris $/ \mathrm{HCl}, \mathrm{pH} 8.0$, containing $150 \mathrm{mM} \mathrm{NaCl}$. Elution was effected with a $1100 \mathrm{ml}$ linear gradient $(0 \cdot 15-0.50 \mathrm{M}$ $\mathrm{NaCl})$ in equilibration buffer at a flow rate of $9 \mathrm{ml} \mathrm{min}^{-1}$. Pooled fractions were dialysed against $50 \mathrm{mM}$ sodium phosphate buffer, $\mathrm{pH} 7 \cdot 0$, containing $1.2 \mathrm{M}$ ammonium sulfate and loaded on a Pharmacia Phenyl Sepharose HP HiLoad 16/10 column equilibrated with the same buffer. Elution was performed with a $230 \mathrm{ml}$ linear gradient (1.2-0.0 M ammonium sulfate) in equilibration buffer at a flow rate of $4 \mathrm{ml} \mathrm{min}^{-1}$. After dialysis against $20 \mathrm{mM}$ Tris $/ \mathrm{HCl}, \mathrm{pH} 6.0$, pooled fractions were loaded on a Pharmacia Mono Q HR 10/10 column equilibrated with the same buffer. FPLC anion-exchange chromatography was carried out as described previously (Bronnenmeier et al., 1991). Gel filtration was performed on a Pharmacia Superdex 200 prepgrade HiLoad 16/60 column equilibrated with $100 \mathrm{mM}$ ammonium acetate, $\mathrm{pH} 6.0$, at a flow rate of $1.5 \mathrm{ml} \mathrm{min}$. Chromatofocusing was carried out on a Pharmacia Mono P HR $5 / 20$ column equilibrated with $25 \mathrm{mM}$ Bis-Tris/ $\mathrm{HCl}, \mathrm{pH} \mathrm{6.5}$. The column was eluted with $50 \mathrm{ml}$ Pharmacia Polybuffer 74, diluted $1: 10$ and adjusted to $\mathrm{pH} \mathrm{3.0} \mathrm{with} \mathrm{HCl}$ at a flow rate of $1 \mathrm{ml} \mathrm{min}^{-1}$.

\section{Analytical methods}

Protein concentrations were measured by the method of Sedmak \& Grossberg (1977). Reducing sugars were determined with the 3,5-dinitrosalicylic acid reagent (Wood \& Bhat, 1988). Uronic acids were detected with the colorimetric reagent 3,5-dimethylphenol as described by Scott (1979). SDS-PAGE was performed in $10 \%(\mathrm{w} / \mathrm{v})$ polyacrylamide slab gels in the presence of $0.1 \%$ SDS according to Laemmli (1970). Acidic sugars and oligosaccharides were analysed by HPLC (Beckman System Gold) at $45^{\circ} \mathrm{C}$ on an Aminex HPX-87H column (Bio-Rad) equipped with a cation $\mathrm{H}$ guard column. Sulfuric acid $(5 \mathrm{mM})$ was used as eluent at a flow rate of $0.8 \mathrm{ml} \mathrm{m^{-1 }}$. TLC was carried out as described previously (Bronnenmeier \& Staudenbauer, 1990). Sugars were detected by spraying the plates with a reagent containing $1.23 \mathrm{~g} p$-anisidine and $1.66 \mathrm{~g}$ phthalic acid in $100 \mathrm{ml}$ ethanol.

\section{RESULTS}

\section{Cellular localization}

Hydrolysis of xylan with concentrated culture supernatant of $T$. saccharolyticum or $C$. stercorarium resulted in the formation of xylose, xylobiose and a third component later identified as mGlcAX3 (Fig. 1). Accumulation of this acidic oligosaccharide suggests a deficiency of $\alpha-D-$ glucuronidase activity in culture supernatants. mGlcAX3, as well as xylobiose, was completely degraded when crude extract from either $T$. saccharolyticum or $C$. stercorarium cells was added to the reaction mixture (Fig. 1). These findings indicate an intracellular localization of the $\alpha$-Dglucuronidase activities of both organisms.

\section{Enzyme purification}

The purification of the $\alpha$-D-glucuronidase present in extracts of cells of $C$. stercorarium grown on xylan from birchwood is summarized in Table 1. The $\alpha$-Dglucuronidase could be clearly separated from other components of the xylanase system by a combination of anion-exchange chromatography on Q Sepharose Fast

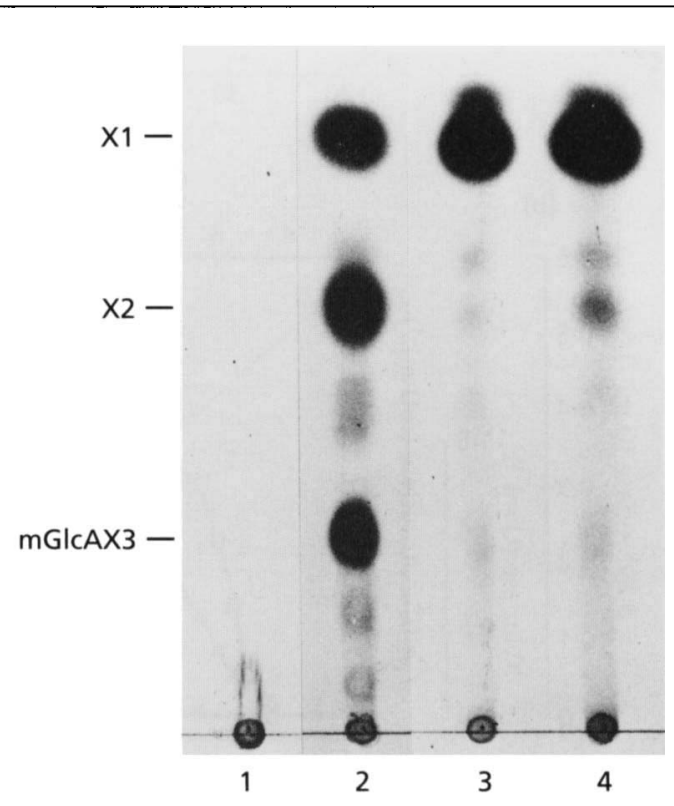

Fig. 1. TLC analysis of the hydrolysis of 4-0-methyl- $\alpha-D-$ glucuronoxylan with crude extracellular and intracellular enzymes. Lanes: 1, 4-0-methyl- $\alpha$-D-glucuronoxylan; 2, 4-0methyl- $\alpha$-D-glucuronoxylan hydrolysed with culture supernatant of $T$. saccharolyticum; $3,4-0$-methyl- $\alpha$-D-glucuronoxylan preincubated with culture supernatant and further hydrolysed with crude extract of $T$. saccharolyticum; 4, 4-O-methyl- $\alpha-D-$ glucuronoxylan pre-incubated with culture supernatant of $T$. saccharolyticum and further hydrolysed with crude extract of $C$. stercorarium. The figure shows representative results for one of at least three experiments. 
Table 1. Purification of $\alpha$-D-glucuronidase from crude extract of $C$. stercorarium

\begin{tabular}{|c|c|c|c|c|c|}
\hline Purification step & $\begin{array}{l}\text { Volume } \\
\text { (ml) }\end{array}$ & $\begin{array}{l}\text { Protein } \\
\text { (mg) }\end{array}$ & $\begin{array}{l}\text { Activity } \\
\text { (U) }\end{array}$ & $\begin{array}{c}\text { Specific } \\
\text { activity } \\
\left(\mathrm{mU} \mathrm{mg}^{-1}\right)\end{array}$ & $\begin{array}{c}\text { Purification } \\
\text { (-fold) }\end{array}$ \\
\hline Crude extract & 148 & 1468 & $7 \cdot 2$ & $4 \cdot 9$ & $1 \cdot 0$ \\
\hline Q Sepharose FF & 320 & 171 & $2 \cdot 6$ & $15 \cdot 2$ & $3 \cdot 1$ \\
\hline Phenyl-Sepharose & 75 & 31 & $1 \cdot 3$ & $43 \cdot 3$ & $8 \cdot 8$ \\
\hline Mono Q pH 6.0 & 21 & 7 & 0.5 & $71 \cdot 4$ & $14 \cdot 6$ \\
\hline Superdex 200 & 18 & 2 & $0 \cdot 3$ & $150 \cdot 0$ & $30 \cdot 6$ \\
\hline Mono P & $2 \cdot 3$ & $0 \cdot 3$ & $0 \cdot 1$ & $333 \cdot 3$ & $68 \cdot 0$ \\
\hline Mono $\mathrm{Q}$ pH 5.0 & $1 \cdot 0$ & 0.03 & 0.05 & $1646 \cdot 9$ & $336 \cdot 1$ \\
\hline
\end{tabular}

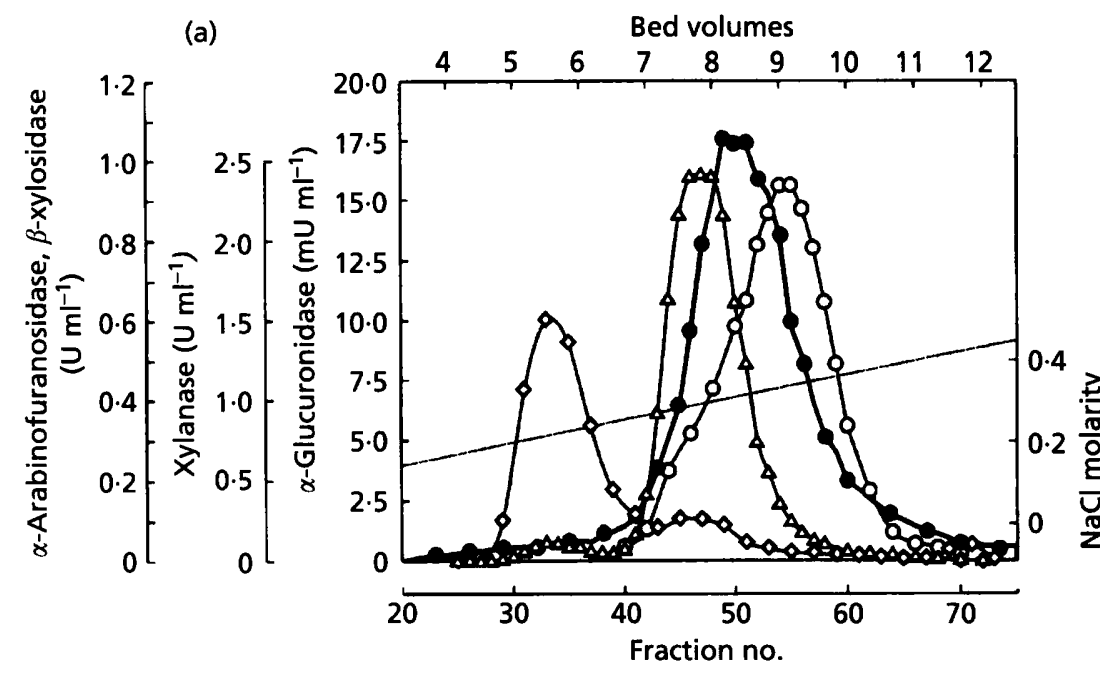

(b)

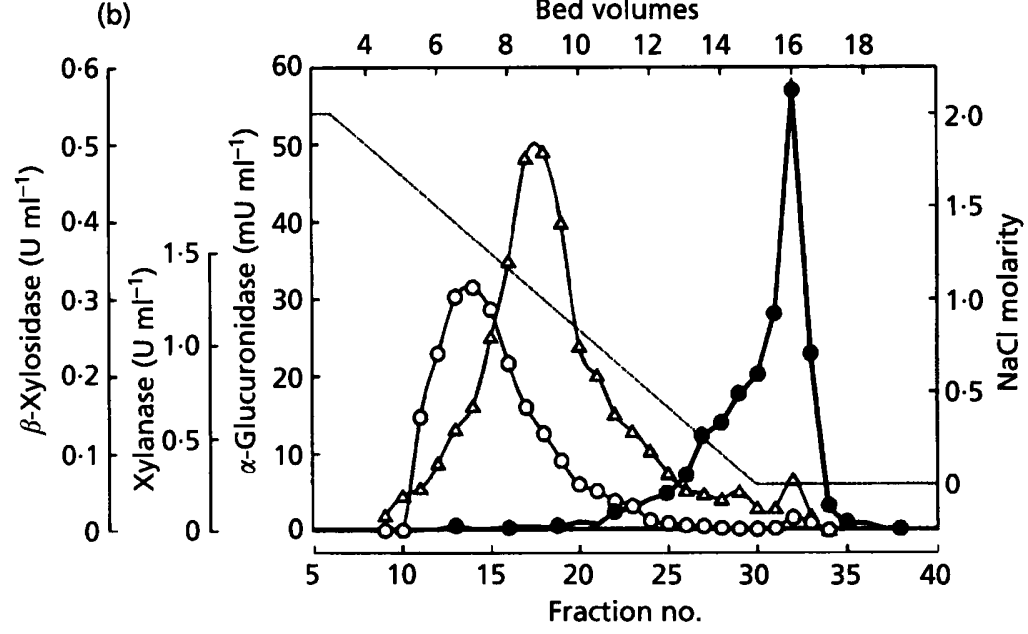

Fig. 2. Fractionation of C. stercorarium enzymes involved in xylan depolymerization by Q Sepharose anion-exchange chromatography (a) and Phenyl-Sepharose hydrophobic interaction chromatography (b). The figure shows representative results for one of two independent experiments. (a) Crude extract was applied to a Q Sepharose Fast Flow XK 50/20 column (bed height $6 \mathrm{~cm}$ ) equilibrated with $20 \mathrm{mM}$ Tris $/ \mathrm{HCl}$, $\mathrm{pH} 8.0$, containing $100 \mathrm{mM} \mathrm{NaCl}$. Elution was performed with a $2040 \mathrm{ml}$ linear gradient $(0.1-0.6 \mathrm{M} \mathrm{NaCl})$ in $20 \mathrm{mM}$ Tris/ $/ \mathrm{HCl}, \mathrm{pH} 8.0$, at a flow rate of $10 \mathrm{ml} \mathrm{min}^{-1}$. Fractions $(20 \mathrm{ml})$ were assayed for $\alpha$-D-glucuronidase (O), $\alpha$-Larabinofuranosidase $(\diamond), \beta$-D-xylosidase $(\triangle)$ and xylanase (O). (b) The $\alpha$-D-glucuronidase pool of the Q Sepharose column (fractions 43-59), adjusted to $2 \mathrm{M} \mathrm{NaCl}$, was applied to a Phenyl-Sepharose HP HiLoad 16/10 column equilibrated with $20 \mathrm{mM}$ Tris/ $\mathrm{HCl}$, pH 8.0, containing $2 \mathrm{M} \mathrm{NaCl}$. Elution was performed with a $276 \mathrm{ml}$ linear gradient $(2.0-0.0 \mathrm{M}$ $\mathrm{NaCl}$ ) in $20 \mathrm{mM}$ Tris/ $\mathrm{HCl}, \mathrm{pH} 8.0$, at a flow rate of $5 \mathrm{ml} \mathrm{min}-1$. Fractions $(11.5 \mathrm{ml})$ were assayed for $\alpha$-D-glucuronidase (O), $\beta$-Dxylosidase $(\triangle)$ and xylanase $(O)$. In both (a) and (b) the $\mathrm{NaCl}$ gradient is shown by a finely dotted line.
Flow and hydrophobic interaction chromatography on Phenyl-Sepharose High Performance columns (Fig. $2 \mathrm{a}, \mathrm{b})$. Further purification was achieved by anionexchange chromatography on Mono Q, chromatofocusing on Mono P and gel filtration on a Superdex 200 column. On the latter column, the enzyme migrated as a peak with an apparent molecular mass of $124 \mathrm{kDa}$.
Analysis of the purified enzyme by SDS-PAGE revealed two protein bands with molecular masses of 72 and $76 \mathrm{kDa}$ (Fig. 3), indicating an oligomeric structure of the $\alpha$-D-glucuronidase. Due to the fact that proteins elute from a Mono $\mathrm{P}$ chromatofocusing column at a $\mathrm{pH}$ close to their isoelectric point, the pI of the purified enzyme was estimated to be $4 \cdot 3$. 


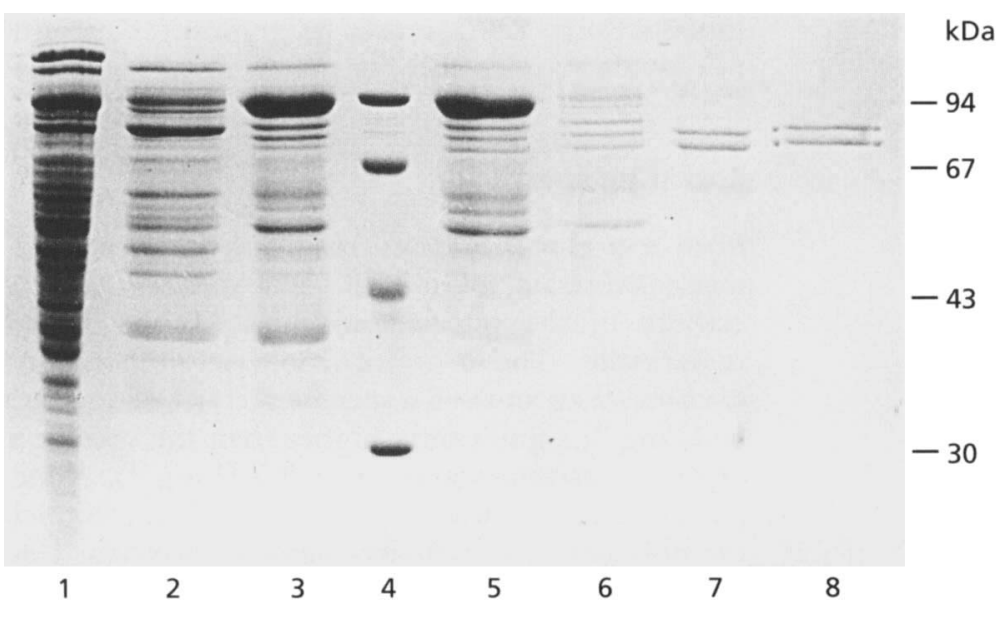

Fig. 3. SDS-PAGE of the fractions obtained during purification of the $\alpha$-D-glucuronidase of $C$. stercorarium. Lanes: 1, crude extract; 2 , pooled fractions from the $Q$ Sepharose column; 3, pooled fractions from the Phenyl-Sepharose column; 4, molecular mass markers (values in $\mathrm{kDa}$ on the right); 5 , pooled fractions from the Mono $Q$ column at $\mathrm{pH} \mathrm{6.0;} \mathrm{6,} \mathrm{pooled} \mathrm{fractions} \mathrm{from} \mathrm{the}$ Superdex column; 7 , pooled fractions from the Mono $P$ column; 8, fraction 22 from the Mono Q column at pH 5.0.

Table 2. Purification of $\alpha$-D-glucuronidase from crude extract of $T$. saccharolyticum

\begin{tabular}{|lrrrcc|}
\hline Purification step & $\begin{array}{c}\text { Volume } \\
\text { (ml) }\end{array}$ & $\begin{array}{c}\text { Protein } \\
\text { (mg) }\end{array}$ & $\begin{array}{c}\text { Activity } \\
\text { (U) }\end{array}$ & $\begin{array}{c}\text { Specific } \\
\text { activity } \\
\left(\mathbf{U ~ m g ~}^{-1}\right)\end{array}$ & $\begin{array}{c}\text { Purification } \\
\text { (-fold) }\end{array}$ \\
\hline Crude extract & 50 & 1479 & 259 & $0 \cdot 2$ & $1 \cdot 0$ \\
Q Sepharose FF & 250 & 173 & 103 & $0 \cdot 6$ & $3 \cdot 0$ \\
Phenyl-Sepharose & 100 & 64 & 67 & $1 \cdot 1$ & $5 \cdot 5$ \\
Mono Q & 14 & 12 & 39 & $3 \cdot 3$ & $16 \cdot 5$ \\
Superdex 200 & 6 & 4 & 24 & $6 \cdot 6$ & $33 \cdot 0$ \\
Mono P & 3 & $0 \cdot 5$ & $4 \cdot 8$ & $9 \cdot 6$ & $48 \cdot 0$ \\
\hline
\end{tabular}

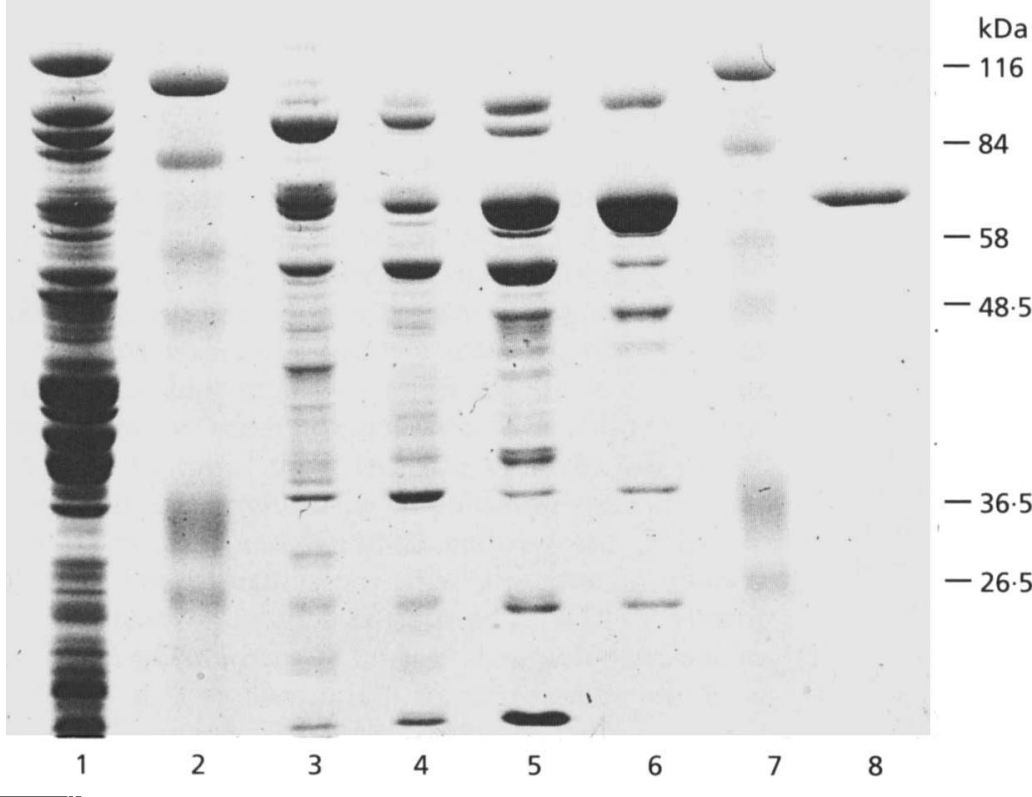

Fig. 4. SDS-PAGE of the fractions obtained during purification of the $\alpha$-D-glucuronidase of $T$. saccharolyticum. Lanes: 1, crude extract; 2 and 7, molecular mass markers (values in $\mathrm{kDa}$ on the right); 3, pooled fractions from the $Q$ Sepharose column; 4, pooled fractions from the Phenyl-Sepharose column; 5, pooled fractions from the Mono $Q$ column; 6, pooled fractions from the Superdex column; 7, fraction 41 from the Mono P column.
The $\alpha$-D-glucuronidase of $T$. saccharolyticum was isolated from the crude extract by a similar purification procedure (Table 2). The purified enzyme ran as a single $71 \mathrm{kDa}$ band in SDS-PAGE (Fig. 4). During gel filtration on a
Superdex 200 column, the enzyme eluted as a single peak with an apparent molecular mass of $118 \mathrm{kDa}$, suggesting a dimeric subunit structure. The pI was determined as $4 \cdot 3$ by chromatofocusing. 

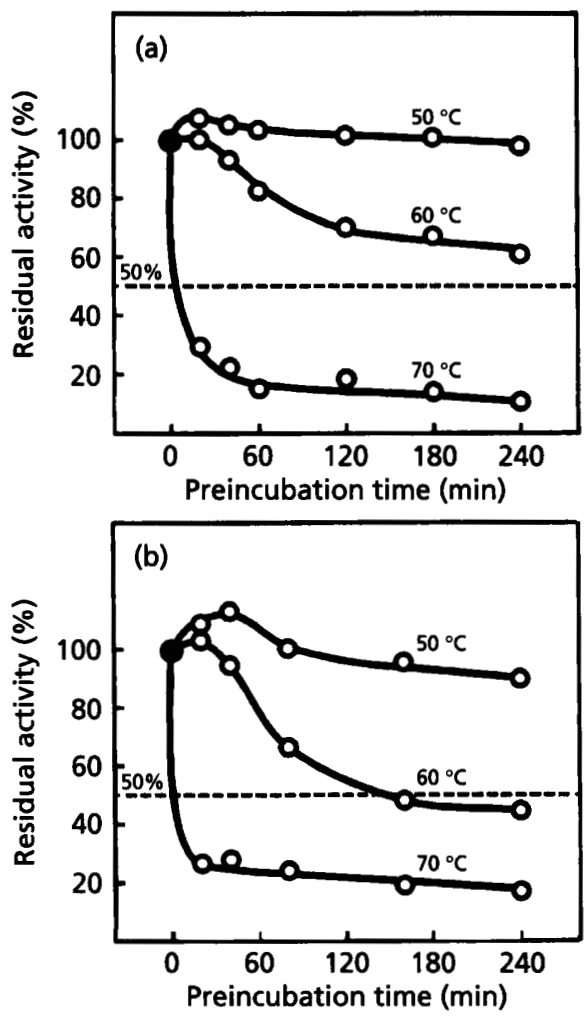

Fig. 5. Thermal stability of $\alpha$-D-glucuronidases from $C$. stercorarium (a) and $T$. saccharolyticum (b) in the absence of substrate. Purified enzymes were incubated in $100 \mathrm{mM}$ sodium succinate, $\mathrm{pH} \mathrm{6.0,} \mathrm{at} \mathrm{various} \mathrm{temperatures.} \mathrm{At} \mathrm{the} \mathrm{times}$ indicated, samples were withdrawn for the determination of $\alpha$ D-glucuronidase activity with the standard assay procedure at $60^{\circ} \mathrm{C}$ for the $\mathrm{C}$. stercorarium enzyme and at $50^{\circ} \mathrm{C}$ for the enzyme of $T$. saccharolyticum. The results shown are representative of three experiments. One hundred percent residual activity of the enzymes of $C$. stercorarium and $T$. saccharolyticum corresponds to $0.14 \mathrm{mU}$ and $1.7 \mathrm{mU}$, respectively.

\section{Effects of pH, temperature and salts on enzyme activity}

Both $\alpha$-D-glucuronidases were maximally active at $\mathrm{pH} 6.0$ and retained at least $40 \%$ activity at $\mathrm{pH}$ values ranging from 5 to 8 . When the enzymes were assayed for $180 \mathrm{~min}$ in $100 \mathrm{mM}$ sodium succinate, $\mathrm{pH} 6.0$, the highest activity was observed at $60^{\circ} \mathrm{C}$ for the C. stercorarium and at $50^{\circ} \mathrm{C}$ for the T. saccharolyticum $\alpha$-D-glucuronidase. In $100 \mathrm{mM}$ sodium succinate buffer, $\mathrm{pH} 6.0$, at an enzyme concentration of $6.4 \mu \mathrm{g} \mathrm{ml}^{-1}$, and without stabilizing additives, the $\alpha$-D-glucuronidase from $C$. stercorarium was stable at $50{ }^{\circ} \mathrm{C}$ (Fig. 5). At $60^{\circ} \mathrm{C}$ the enzyme exhibited a half-life of about $14 \mathrm{~h}$. The enzyme of $T$. saccharolyticum was less thermostable, showing a half-life of $2-3 \mathrm{~h}$ at $60^{\circ} \mathrm{C}$. Addition of bovine serum albumin $\left(10 \mathrm{mg} \mathrm{ml}^{-1}\right)$ and/or $\mathrm{Ca}^{2+}(20 \mathrm{mM})$ did not stabilize the purified enzyme. The purified $\alpha$-D-glucuronidases of both organisms were strongly inhibited by $\mathrm{CuCl}_{2}$. At a concentration of $1 \mathrm{mM}$, the $C$. stercorarium enzyme suffered a $74 \%$ loss of activity and the enzyme from $T$. saccharolyticum lost $80 \%$ of its initial activity. $\mathrm{ZnCl}_{2}$ caused a significant reduction (40\%) in enzyme activity only for the $C$. stercorarium enzyme.

\section{Substrate specificity}

Both $\alpha$-D-glucuronidases readily hydrolysed the oligomeric substrate mGlcAX3. The differences in specific activity of the purified enzymes (Tables 1 and 2) is remarkable. The $\alpha$-D-glucuronidase preparation of $T$. saccharolyticum showed a specific activity of approximately $10 \mathrm{U} \mathrm{mg}^{-1}$, significantly higher than the specific activity of the $C$. stercorarium enzyme $\left(1.7 \mathrm{U} \mathrm{mg}^{-1}\right)$. None of the purified enzymes was able to release glucuronic acid from the polymer $4-O-$-methyl- $\alpha$-D-glucuronoxylan. Under the conditions of the assay, the lower detection limit was $3.7 \mathrm{mU} \mathrm{mg}^{-1}$ and $0.5 \mathrm{mU} \mathrm{mg}^{-1}$ for the T. saccharolyticum and $C$. stercorarium enzymes, respectively. Since chromogenic aryl-glycosides are commonly used for the determination of hydrolase activity we synthesized a $p$ nitrophenyl- $\alpha$-D-glucuronide according to Marsh (1952) and Marsh \& Levvy (1958). Neither the $\alpha$-D-glucuronidase of $C$. stercorarium nor that of $T$. saccharolyticum was able to hydrolyse the $\alpha$-glycosidic bond of the arylsubstrate. The lower detection limit was $4.2 \mathrm{mU} \mathrm{mg}^{-1}$ and $0.6 \mathrm{mU} \mathrm{mg}^{-1}$ for the $T$. saccharolyticum and $C$. stercorarium enzymes, respectively, under the conditions of the $p$-nitrophenyl- $\alpha$-D-glucuronidase assay.

\section{DISCUSSION}

$\alpha$-D-Glucuronidase activity has been detected in a variety of fungi (Puls, 1992). The enzymes from Thermoascus aurantiacus (Khandke et al., 1989), Agaricus bisporus (Puls et al., 1987; Puls, 1992), Aspergillus niger (Uchida et al., 1992), Trichoderma reesei (Puls, 1992), and Trichoderma reesei RUT C-30 (Siika-aho et al., 1994) have been purified thus far. Amongst bacteria, $\alpha$-D-glucuronidase activity has been identified in Streptomyces olivocbromogenes (MacKenzie et al., 1987), Fibrobacter succinogenes (Smith \& Forsberg, 1991), Clostridium acetobutylicum (Trudeau et al., 1992) and Thermotoga maritima (Bronnenmeier et al., 1995). The enzymes of $C$. stercorarium and $T$. saccharolyticum reported in this paper are the first $\alpha$-D-glucuronidases which have been purified to homogeneity from bacterial sources. While the enzymes purified from fungi all have a comparably high monomeric molecular mass of more than $100 \mathrm{kDa}$, the purified bacterial enzymes described here consist of subunits with molecular masses of approximately $70 \mathrm{kDa}$. The specific activity towards mGlcAX3 of the enzyme purified from $C$. stercorarium $\left(1 \cdot 7 \mathrm{U} \mathrm{mg}^{-1}\right)$ is of the same order of magnitude as that reported for the $\alpha$-D-glucuronidase of the fungus Thermoascus aurantiacus $\left(2 \cdot 2 \mathrm{U} \mathrm{mg}^{-1}\right)$ towards the same substituted xylo-oligomer (Khandke et al., 1989). The specific activity of the T. saccbarolyticum enzyme $\left(10 \mathrm{U} \mathrm{mg}^{-1}\right)$ is comparable to that reported recently for the purified enzyme of Trichoderma reesei RUT C-30 (Siika-aho et al., 1994).

Hydrolysis of side-chains in high-molecular-mass glucuronoxylan could not be detected with $\alpha$-D- 
glucuronidase preparations of $C$. stercorarium and $T$. saccharolyticum. This is consistent with the intracellular localization of both enzymes. The enzymes from Agaricus bisporus (Puls, 1992), Fibrobacter succinogenes (Smith \& Forsberg, 1991) and Streptomyces olivochromogenes (Fontana et al., 1988) were also unable to release glucuronic acid from the polymeric substrate. Minor activity against longchain glucuronoxylan was reported for the enzyme of Trichoderma reesei RUT C-30 (Siika-aho et al., 1994). In contrast, the $\alpha$-D-glucuronidase from Aspergillus niger, Schizophyllum commune and Thermoascus aurantiacus effected the liberation of 4-O-methyl- $\alpha$-D-glucuronic acid from glucuronoxylan (Coughlan \& Hazlewood, 1993; Khandke et al., 1989). In all cases, substituted xylooligomers proved to be better substrates with respect to relative rates of hydrolysis. The synthetic $p$-nitrophenyl$\alpha$-D-glucuronoside was not cleaved by the enzymes from $C$. stercorarium and T. saccharolyticum. A lack of aryl- $\alpha$-Dglucuronidase activity has also been reported for the purified enzyme of Aspergillus niger 5-16 (Uchida et al., 1992) and a crude xylanolytic enzyme preparation of Streptomyces olivocbromogenes (Fontana et al., 1988).

The isolation of $\alpha$-D-glucuronidase from thermophilic anaerobes indicates that these bacteria produce complete sets of xylanolytic enzymes for the degradation of glucuronoxylan. Since $\alpha$-D-glucuronidase proved to be an intracellular enzyme, the complete hydrolysis of glucuronoxylan must result from the co-operative action of intra- and extracellularly located enzymes in these bacteria. The high-molecular-mass xylan is degraded outside the cells by the main-chain hydrolysing enzymes endoxylanase and $\beta$-xylosidase. The products - xylose, xylobiose and 4-O-methyl- $\alpha$-D-glucuronosyl-xylotriose are transported into the cells, where the side-chain glucuronosyl residues are removed by $\alpha$-D-glucuronidase action. The resulting xylotriose and the extracellularly produced xylobiose may then be further degraded to xylose by an intracellular $\beta$-xylosidase (K. Bronnenmeier, unpublished results).

\section{ACKNOWLEDGEMENTS}

We wish to thank Drs R. B. Hespell and P. J. Weimer for kindly providing Thermoanaerobacter saccharolyticum. We are grateful to Professor Dr F. P. Schmidtchen for the possibility to synthesize the chromogenic substrate $p$-nitrophenyl-Dglucuronoside in his laboratory. This work was supported by a grant (SFB 145) from the Deutsche Forschungsgemeinschaft.

\section{REFERENCES}

Aspinall, G. O. (1980). Chemistry of cell wall polysaccharides. In The Biochemistry of Plants, pp. 473-500. Edited by N. E. Tolbert. New York: Academic Press.

Bronnenmeier, K. \& Staudenbauer, W. L. (1988). Purification and properties of an extracellular $\beta$-glucosidase from the cellulolytic thermophile Clostridium stercorarium. Appl Microbiol Biotechnol 28, 380-386.

Bronnenmeier, K. \& Staudenbauer, W. L. (1990). Cellulose hydrolysis by a highly thermostable endo-1,4- $\beta$-glucanase (Avicelase I) from Clostridium stercorarium. Enzyme Microb Tecbnol 12, 431-436.

Bronnenmeier, K., Ebenbichler, C. \& Staudenbauer, W. L. (1990).
Separation of the cellulolytic and xylanolytic enzymes of Clostridium stercorarium. J Chromatogr 521, 301-310.

Bronnenmeier, K., Rucknagel, K. P. \& Staudenbauer, W. L. (1991). Purification and properties of a novel type of exo-1,4- $\beta$-glucanase (Avicelase II) from the cellulolytic thermophile Clostridium stercorarium. Eur J Biochem 200, 379-385.

Bronnenmeier, K., Kern, A., Liebl, W. \& Staudenbauer, W. L. (1995). Purification of Thermotoga maritima enzymes for the degradation of cellulosic materials. Appl Environ Microbiol 61, 1399-1407.

Coughlan, M. P. \& Hazlewood, G. P. (1993). $\beta-1,4-D-X y l a n-$ degrading enzyme systems: biochemistry, molecular biology and applications. Biotechnol Appl Biochem 17, 259-289.

Fontana, J. D., Gebara, M., Blumel, M., Schneider, H., Mackenzie,

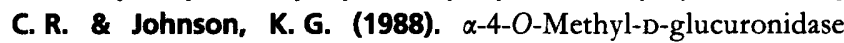
component of xylanolytic complexes. Methods Enzymol 160, 560-571.

Hespell, R. B. (1992). Fermentation of xylans by Butyrivibrio fibrisolvens and Thermoanaerobacter strain B6A: utilization of uronic acids and xylanolytic activities. Curr Microbiol 25, 189-195.

Johnson, E. A., Madia, A. \& Demain, A. L. (1981). Chemically defined minimal medium for growth of the anaerobic cellulolytic thermophile Clostridium thermocellum. Appl Environ Microbiol 41, 1060-1062.

Khandke, K. M., Vithayayathil, P. J. \& Murthy, S. K. (1989). Purification and characterization of an $\alpha$-D-glucuronidase from a thermophilic fungus, Thermoascus aurantiacus. Arch Biochem Biophys 274, 511-517.

Laemmli, U. K. (1970). Cleavage of structural proteins during the assembly of the head of bacteriophage T4. Nature 227, 680-685.

Lee, Y.-E., Jain, M. K., Lee, C., Lowe, S. E. \& Zeikus, J. G. (1993a). Taxonomic distinction of saccharolytic thermophilic anaerobes: description of Thermoanaerobacterium xylanolyticum gen. nov., sp. nov., and Thermoanaerobacterium saccharolyticum gen. nov., sp. nov.; reclassification of Thermoanaerobium brockii, Clostridium thermosulfurogenes, and Clostridium thermobydrosulfuricum E100-69 as Thermoanaerobacter brockii comb. nov., Thermoanaerobacterium thermosulfurigenes comb. nov., and Thermoanaerobacter thermobydrosulfuricus comb. nov., respectively; and transfer of Clostridium thermobydrosulfuricum $39 \mathrm{E}$ to Thermoanaerobacter ethanolicus. Int J Syst Bacteriol 43, 41-51.

Lee, Y.-E., Lowe, S. E. \& Zeikus, J. G. (1993b). Regulation and characterization of xylanolytic enzymes of Thermoanaerobacterium saccbarolyticum B6A-RI. Appl Environ Microbiol 59, 763-771.

Mackenzie, C. R., Bilous, D., Schneider, H. \& Johnson, K. G. (1987). Induction of cellulolytic and xylanolytic enzyme systems in Streptomyces spp. Appl Environ Microbiol 53, 2835-2839.

Madden, R. A. (1983). Isolation and characterization of Clostridium stercorarium sp. nov., cellulolytic thermophile. Int J Syst Bacteriol 33, 837-840.

Marsh, C. A. (1952). The synthesis of conjugated hexuronic acids. J Chem Soc 1578-1582.

Marsh, C. A. \& Levvy, G. A. (1958). The synthesis of aryl glycosiduronic acids. Biochem J 68, 617-621.

Milner, Y. \& Avigad, G. (1967). A copper reagent for the determination of hexuronic acids and certain ketohexoses. Carbobydr Res 4, 359-361.

Puls, J. (1992). $\alpha$-Glucuronidases in the hydrolysis of wood xylans. In Xylans and Xylanases, pp. 213-224. Edited by J. Visser, G. Beldman, M. A. Kusters-van Someren \& A. G. J. Voragen. Amsterdam: Elsevier. 
Puls, J. \& Poutanen, K. (1989). Mechanism of enzyme hydrolysis of hemicelluloses (xylans) and procedures for determination of the enzyme activities involved. In Enzyme Systems for Lignocellulose Degradation, pp. 151-165. Edited by M. P. Coughlan. London: Elsevier Applied Science.

Puls, J., Schmidt, O. \& Granzow, C. (1987). $\alpha$-Glucuronidase in two microbial xylanolytic systems. Envyme Microb Technol 9, 83-88.

Schwarz, W. H., Adelsberger, H., Jauris, S., Hertel, C., Funk, B. \& Staudenbauer, W. L. (1990). Xylan degradation by the thermophile Clostridium stercorarium: cloning and expression of xylanase, $\beta$-Dxylosidase, and $\alpha$-L-arabinofuranosidase genes in Escherichia coli. Biochem Biophys Res Commun 170, 368-374.

Scott, R. W. (1979). Colorimetric determination of hexuronic acids in plant materials. Anal Chem 51, 936-941.

Sedmak, J. J. \& Grossberg, S. E. (1977). A rapid, sensitive assay for protein using Coomassie brilliant blue G250. Anal Biochem 79, 544-552.

Siika-aho, M., Tenkanen, M., Buchert, J., Puls, J. \& Viikari, L. (1994). An $\alpha$-glucuronidase from Trichoderma reesei RUT C-30. Enzyme Microb Technol 16, 813-819.

Smith, D. C. \& Forsberg, C. W. (1991). $\alpha$-Glucuronidase and other hemicellulase activities of Fibrobacter succinogenes S85 grown on crystalline cellulose or ball-milled barley straw. Appl Environ Microbiol 57, 3552-3557.

Trudeau, D. G., Bernier, R. L., Gannon, D. J. \& Forsberg, C. W. (1992). Isolation of Clostridium acetobutylicum strains and the preliminary investigation of the hemicellulolytic activities of isolate 3BYR. Can J Microbiol 38, 1120-1127.

Uchida, H., Nanri, T., Kawabata, Y., Kusakabe, L. \& Murakami, K. (1992). Purification and characterization of intracellular $\alpha$ glucuronidase from Aspergillus niger 5-16. Biosci Biotech Biochem 56, 1608-1615.

Weimer, P. J. (1985). Thermophilic anaerobic fermentation of hemicellulose and hemicellulose-derived aldose sugars by Thermoanaerobacter strain B6A. Arch Microbiol 143, 130-136.

Weimer, P. J., Wagner, W., Knowlton, S. \& Ng, T. K. (1984). Thermophilic anaerobic bacteria which ferment hemicellulose: characterization of organisms and identification of plasmids. Arch Microbiol 138, 31-36.

Wood, T. M. \& Bhat, K. M. (1988). Methods for measuring cellulase activities. Methods Enzymol 160, 87-112.

Received 30 December 1994; revised 5 April 1995; accepted 26 April 1995. 